\title{
Technological aspects related to the use of bifidobacteria in dairy products
}

\author{
Denis ROY* \\ Institute of Nutraceuticals and Functional Foods and Centre STELA, Laval University, \\ Quebec City, Quebec, Canada
}

\begin{abstract}
Dairy-related bifidobacteria are already used in a wide variety of probiotic dairy products including milk, cheese, frozen yoghurt-like product and ice cream. The survival of bifidobacteria in fermented dairy products depends on varied factors such as the strain of bacteria used, fermentation conditions, storage temperature, and preservation methods. Growth of bifidobacteria in milk is often slow or limited compared with lactic acid bacteria used in fermented dairy products, and this appears partially due to low proteolytic activities. When manufacturing cheese or yoghurt-like product, addition of probiotic cultures to the normal starters generally results in slower growth of the probiotic strains than if they were added alone in milk. The use of higher inocula of bifidobacteria and the addition of growth promoting factors as a nitrogen source should further enhance the growth and viability of the bifidobacteria. Although the most common processing stage at which to add the bifidobacteria to the milk would be in conjunction with the other starter cultures, other alternative processing protocols have been successful in incorporating the bifidobacteria into cheese and cultured dairy products. The success of the incorporation of bifidobacteria into cheeses is dependent on the bifidobacteria strains, the activity of lactic acid bacteria used in the manufacture of the cheese, the composition of the cheese, and the conditions of processing and ripening. Changes in the chemical composition and the texture of the fermented products can occur in cheeses and fermented milks without affecting sensorial properties.
\end{abstract}

\section{Bifidobacterium / yoghurt-like product / cheese / viability / stability}

Résumé - Les aspects technologiques de l'utilisation des bifidobactéries dans les produits laitiers. Les bifidobactéries d'intérêt laitier sont déjà employées dans une grande variété de produits laitiers probiotiques comme le lait, le fromage, le yaourt congelé et la crème glacée. La survie des bifidobactéries dans les produits laitiers fermentés dépend de facteurs divers tels que la souche des bactéries utilisées, les conditions de fermentation, la température d'entreposage et les conditions de conservation. La croissance des bifidobactéries dans le lait est souvent lente ou limitée comparée à celle des bactéries lactiques utilisées dans produits laitiers fermentés, et ceci semble partiellement dû à de faibles activités protéolytiques. En fabriquant le fromage ou le yaourt, l'addition des cultures probiotiques aux ferments a généralement comme conséquence une croissance plus lente des souches probiotiques comparé à si elles étaient ajoutées au lait seules. L'utilisation de plus hauts niveaux d'inoculum de bifidobactéries et l'addition de facteurs de croissance comme la source d'azote devraient améliorer la croissance et la viabilité des bifidobactéries. Bien que la pratique la plus commune serait d'ajouter les bifidobactéries au lait en même temps que les autres ferments, d'autres protocoles de traitement alternatifs ont été proposés pour incorporer les bifidobactéries dans les fromages et les produits laitiers fermentés. Le succès de l'incorporation des bifidobactéries

\footnotetext{
* Corresponding author: Denis.roy@inaf.ulaval.ca
} 
dans les fromages dépend des souches de bifidobactéries, de l'activité des bactéries lactiques utilisées dans la fabrication du fromage, de la composition du fromage, et des conditions de fabrication et d'affinage. Les changements de la composition chimique et de la texture des produits fermentés peuvent se produire dans les fromages et les laits fermentés à la suite de l'incorporation des bifidobactéries, sans affecter les propriétés sensorielles.

\section{Bifidobacterium / yaourt / fromage / viabilité / stabilité}

\section{INTRODUCTION}

During the last 35 years, attempts have been made to improve the health status of human by modulating the intestinal microflora using live microbial adjuncts called probiotics. Indeed, different products containing probiotic bacteria have gained in popularity with consumers. Strains of Lactobacillus acidophilus and Lactobacillus casei complex are well represented in commercial probiotic products, followed by Bifidobacterium spp. (B. animalis subsp. lactis, B. bifidum, B. breve, B. longum subsp. infantis and $B$. longum), some other lactic acid bacteria (lactococci, leuconostocs, enterococci) and non-lactic acid bacteria (propionibacteria and yeasts) [29].

The incorporation of bacteria of intestinal origin into human diet corresponds to the emergence of functional food, which uses the beneficial effects of these bacteria on intestinal metabolism [46]. Functional food can be defined as any food that may provide a health benefit beyond the traditional nutrients it contains.

Bifidobacteria are emerging as possibly one of the most important group of intestinal organisms with regard to human health. It is estimated that over 400 species of bacteria inhabit the human gastrointestinal tract and Bifidobacterium spp. belongs to the dominant anaerobic flora of the colon. The main species present in human colon are $B$. adolescentis, $B$. bifidum, B. longum subsp. infantis, B. breve and B. longum [29].

Dairy products appear to be good vehicles for the delivery of probiotics to humans. B. bifidum, B. longum subsp. infantis, B. longum and B. animalis subsp. lactis are com- monly used for the production of fermented milks $[53,76]$. Dairy products containing bifidobacteria are made with pure cultures, alone or in combination with other lactic acid bacteria such as Streptococcus thermophilus, Lactobacillus delbrueckii subsp. bulgaricus, and L. acidophilus group or L. casei group [36]. Dairy-related bifidobacteria are already used in a wide variety of probiotic dairy products including milk, bifidus milk, cheese, frozen yoghurt-like product and ice cream. Yoghurt-like products are made using a single species of bifidobacteria in combination with lactic acid bacteria. Bifidobacteria can be incorporated to yoghurtlike products before or after fermentation. Fermented milks containing B. longum or $B$. breve have obtained "Foods for specific health use" (FOSHU) approval in Japan which are recognized to regulate intestinal microflora and allow a healthier gastrointestinal condition.

The aim of this review is to address the technological factors involved in the use of bifidobacteria as probiotics: addition level, selection criteria, incorporation in fermented milks and cheese, stability during storage and change in sensorial properties. This review is a complement to many excellent reviews that have been published on development of functional foods with bifidobacteria [8, 63, 68, 72].

\section{RECOMMENDED ADDITION LEVEL}

According to Marteau and Shanahan [40], the best criterion for the expression of the results in pharmacokinetics studies is probably the concentration of probiotic at the target site. Probiotic products containing 
bifidobacteria should be standardized on the basis of viable count because it is presumed that probiotic viability is a reasonable measure of probiotic activity. The number of cells present in products is a useful indicator to estimate the probiotic viability with the assumption that this is the important factor to consider in product functionality. To perform this functionality, probiotics must be viable at the time of consumption and maintain their viability throughout the gastrointestinal tract. Recommendations for the minimum suggested level for probiotics in product to attain this viability are quite variable. More critical than the concentration of probiotics in the functional food, however, is the daily intake of the probiotics necessary to attain a therapeutic effect. The concentration of probiotics needed to obtain a clinical effect is often quoted as $\geq 10^{6} \mathrm{cfu} \cdot \mathrm{mL}^{-1}$ in the small bowel and $\geq 10^{8} \mathrm{cfu} \cdot \mathrm{g}^{-1}$ in the colon although a therapeutic minimum dose of $1 \times 10^{5}$ viable cells/g or $\mathrm{mL}$ product was proposed $[39,73]$. The small bowel concentration limit has been proposed because it leads to a clinical effects (diarrhoea) in subjects with bacterial colonization of the small bowel; the concentration in the colon has been proposed as it represents the lower limit of the dominant flora [11, 40]. Hence, a daily intake of at least $10^{8}-10^{9}$ viable cells has been suggested as the minimum intake to provide a therapeutic effect $[21,71]$. However, the dose required for a probiotic effect may be dependent on the food form in which the probiotic is ingested and on the probiotic strain used.

In general, the food industry has targeted populations of $\geq 10^{6} \mathrm{cfu} \cdot \mathrm{g}^{-1}$ at the time of consumption of strain that has been added to food. Initially, this standard appears to have been adopted to provide bacterial concentrations that were technologically attainable and cost-effective, rather than to achieve a specific health effect in humans $[8,57$, 66]. As more data on bacterial population requirements are available, it becomes clear that numbers will vary as a function of the strain and the health effect desired. However, it would be impossible to control microbial counts of probiotic products at the time of consumption. The manufacturers have the responsibility to undertake shelf-life tests at the date of minimum durability; at the point of sale to the consumer; and at the time when the product leaves the manufacturer. Separate minimum counts should be developed for individual micro-organisms such as probiotics bacteria.

\section{SELECTION CRITERIA OF BIFIDOBACTERIA}

Selection of probiotics can be based on general microbiological criteria that refer to safety, technology, performance and health benefits [20]. From the safety's point of view, bifidobacteria are considered to be beneficial for the host by inhibiting the growth of potential harmful bacteria in the intestinal tract and by exhibiting beneficial effects for the host. The production of lactic acid and acetic acid contributes to the bifidobacteria's defence against pathogens through the toxic effect of the undissociated acids on the microorganisms and stimulation of intestinal peristalsis. Administration of probiotics has been proposed to increase the number of bifidobacteria in the gastrointestinal tract. The widespread use of bifidobacteria in fermented foods and dairy products has a long history, and most strains are considered commensal microorganisms with no pathogenic potential. No case of local or systemic infections, including septicemia, meningitis, and endocarditis occurred due to dairy-related bifidobacteria has been reported.

Strain selection based on technological aptitudes is a critical aspect of developing a probiotic-based functional food. Probiotic bacteria must exhibit resistance to technological processes used in preparing the vehicle of probiotic delivery [43]. Unfortunately, not all strains of bifidobacteria can be easily produced industrially because of low yields in the growth media or poor survival 
to freezing or freeze-drying [67], and not all promising strains can be marketed. The selection of a probiotic strain to be added in the product is a crucial step.

High viable counts and survival rates during stomach passage are necessary to allow live bifidobacteria from the fermented milk products to play a biological role in the human intestine. Many bifidobacteria added to dairy products may not exert probiotic effects because they die after exposure to acid during or after fermentation, oxygen during refrigerated distribution and storage, and/or acid in the human stomach [43]. Delivery of viable bifidobacteria to the large intestine, where they would be able to function, has been limited because of the extreme acidity found in the human stomach [2]. Thus, the success of food products containing bifidobacteria depends on the viability of bifidobacteria in the product during its shelf life as well as on the resistance of the bacteria to the conditions system existing in the upper gastrointestinal tract [74]. The survival of bifidobacteria at the $\mathrm{pH}$ values of fermented dairy products and gastric fluid varies. In one strain of bifidobacteria, growth was inhibited by only $0.5 \log$ units, whereas population levels declined by $4 \log$ units in the other strain [2]. B. bifidum was found to be tolerant to the acidity of a model gastrointestinal tract system, with only a $20 \%$ decrease in numbers as the $\mathrm{pH}$ decreased from 5.0 to 1.8 over an $80 \mathrm{~min}$ period [41]. The viability of $B$. animalis subsp. lactis remained unchanged at a $\mathrm{pH}$ of 3 for $180 \mathrm{~min}$, declined slowly at a $\mathrm{pH}$ of 2 , and was zero after $60 \mathrm{~min}$ at a $\mathrm{pH}$ of 1 [51]. B. animalis subsp. lactis exhibited much greater tolerance to human gastric juice than towards simulated gastric juice containing milk protein and mucin. However, it is not clear why this occurred [10]. Viability of bifidobacteria, as expected, depends on the $\mathrm{pH}$, the length of the exposure to acid, and the species and strains used $[3,10]$.

In the small intestine, tolerance to bile salts is an important factor which contrib- utes to the probiotic survival. Experiments involving human intubation and sampling of $B$. animalis subsp. lactis from the cecum showed that these probiotics, when given in fermented milk, survive to the extent of $23.5 \%$ of the administered dose [51]. The delivery of $B$. bifidum and L. acidophilus to the cecum was $\approx 30 \%$ and $10 \%$ of the administered dose, respectively [41]. In comparison, it has been observed that the concentration of viable yoghurt bacteria reaching the duodenum after the ingestion of yoghurt containing $10^{7} \mathrm{cfu} \cdot \mathrm{mL}^{-1}$ was at its peak around $10^{5} \mathrm{cfu} \cdot \mathrm{mL}^{-1}$ [50]. Intrinsic resistance to gastric acid and bile of $L$. delbrueckii subsp. bulgaricus and S. thermophilus is poor [10]. Bifidobacteria survived passage through the stomach and small intestine in humans and reached the appropriate fecal concentrations to exert metabolic activities, but did not colonize the human colon $[6,7]$. In summary, many variables can determine the degree to which probiotics survive passage through the upper gastrointestinal tract: the degree of stomach acidity, the length of exposure to acid, the concentration of and length of exposure to bile salts, the level of bile salt hydrolase activity, and other as yet unspecified properties of the probiotics themselves [3]. It has been noted that, whereas the majority of bile salts-resistant bifidobacteria may be intrinsically sensitive to gastric transit, they are intrinsically resistant to small intestinal transit [10].

The mucosal adhesion of bifidobacteria might be strain-specific and dependent on substrate availability such as mucins [27]. The mucus covering the epithelial cells is the initial surface that ingested microorganisms confront in the human gut. Mucus is continually subjected to degradation; conversely new mucins are constantly secreted. Mucins are high molecular mass glycoproteins that are synthesized and secreted by the goblet cells. They form a gel-like layer on the mucosal surface, and provide favourable conditions for the resident microbiota by forming a specific micro-environment. Thus, bacteria able to adhere to mucus but unable to reach the epithelial 
cells might be dislodged from the mucosal surface with the degraded mucin and washed away with the luminal contents. This may partly explain the transient pattern of colonisation characteristic for most probiotic bacteria [33, 49]. In addition, it is postulated that milk proteins and mucin may function as both buffering agents and inhibitors of digestive protease activity in vivo, thereby protecting ingested bacterial strains during upper gastrointestinal transit.

The viability of probiotic bacteria is affected by inhibitory substances such as lactic acid produced during production and cold storage. During production of yoghurtlike product, yoghurt bacteria and probiotic bacteria produce sufficient hydrogen peroxide to be auto-inhibitory [61]. High numbers of viable bifidobacteria in yoghurt-like product may not always be maintained because of the acidity of yoghurt-like product, the low acid tolerance of bifidobacteria and the cell death due to oxygen toxicity [3, 9]. Acid tolerance is an important property of probiotic bifidobacteria, enabling the cells to survive gastric acidity and volatile fatty acids produced during fermentation in the intestine. Bifidobacteria encounter $\mathrm{pH}$ values ranging from 2.0 to 8.0 in the stomach, depending upon whether food is being consumed and must resist to exposure to $\mathrm{pH} 3$ for 1.5 to $2 \mathrm{~h}$. In addition, survival of ingested bifidobacteria in the stomach obviously is influenced by the buffering capacity of food components [10]. Mature Cheddar cheese compares very favourably with fresh yoghurt-like product as a delivery system for viable probiotic microorganisms to the gastrointestinal tract [19]. On the other hand, survival in fermented milk during long-term storage is a complex process because it is influenced by other stress factors including oxygen, light, nutrient exhaustion and metabolites other than organic acids produced during fermentation [75]. Difference in acid tolerance between yoghurt bacteria and bifidobacteria suggest that various responses of cytoplasmic $\mathrm{pH}$ homeostasis system may occur [75].
The performance aspects for selection of strains should include the following criteria: strains claimed to be present in a product should survive in relatively high viable cell numbers, retain metabolic activity and provide desirable sensorial properties [28]. The survival of bifidobacteria for example in fermented dairy products depends on varied factors such as the strain of bacteria used, fermentation conditions, storage temperature, and preservation methods [68]. One strategy for enhancing bacterial tolerance to stress such as temperature or $\mathrm{pH}$ is prior exposure to sub-lethal levels of the given stress. The stress response phenomenon, which occurs when this treatment results in greater survival, has been widely reported for a variety of micro- and macro-organisms $[43,64]$. Rapid growth rate and rapid acidification of milk are important criteria for the selection of probiotic bacteria. These characteristics of probiotics would reduce costs by requiring short incubation times during the manufacture of fermented dairy products.

The presence of bifidobacteria in the human intestine is almost universally accepted to be a contributing factor to a healthy wellbeing. There is accumulating evidence that bifidobacteria are associated with beneficial health effects. It has been claimed that ingestion of specific bifidobacteria could contribute to reestablishment of a bifidobacterial flora in humans after antibiotic therapy; alleviation of constipation; prevention against diarrhea and other gastrointestinal infections and; alleviation of the symptoms of lactose intolerance [48]. The biological effect of the probiotic culture is generally linked to the strain used, as well as the form and the numbers consumed [3].

\section{TECHNOLOGICAL PERSPECTIVES}

From the manufacturer's point of view, the effects of the environment of the dairy product during processing and storage must also be considered to ensure that the 
concentration of bifidobacteria at the time of consumption provides a therapeutic dose to consumers. Strain of bifidobacteria must exhibit resistance to technological processes used in preparing the vehicle of probiotic delivery. However, the survival of bifidobacteria in fermented milk is mainly limited by their sensitivity to the high acidity. Only a few Bifidobacterium strains seem to be suitable to obtain sufficiently large numbers of viable cells at the time of consumption of these products. In addition, the growth of bifidobacteria seems to be suppressed in the presence of yoghurt starter organisms. However, compared with yoghurt bacteria, bifidobacteria have a higher resistance to acid and bile present in the gastrointestinal tract. The ingestion of bifidus fermented milk led to an increase in total bifidobacteria which was related to the colonic transit of the exogenous bifidobacteria [7].

\subsection{Dairy products production}

Growth of bifidobacteria in milk is often slow or limited compared with other lactic acid bacteria used in fermented dairy products, and this appears partially due to low proteolytic activities [14, 25]. Probiotic bacteria are added to fermented milks, in which the consumer expects the presence of live bacteria. Starters such as lactococci, thermophilic lactobacilli or streptococci are always added for technological purposes (acidification, texture, flavour). Lactobacilli have also become important as adjunct cultures for the production of bifidobacteriacontaining dairy products especially the L. acidophilus group (L. acidophilus and L. johnsonii) and L. casei group (L. casei and L. rhamnosus).

When manufacturing cheese or yoghurtlike product, addition of probiotic cultures to the normal starters generally results in slower growth of the probiotic strains than if they were added alone in milk [59, 65]. These starters produce environments that inhibit the growth of not only pathogens and spoilage microorganisms, but also of probiotic [79]. The phenomenon could par- tially be related to the production of bacteriocins or other inhibitors such as lactic and other organic acids and hydrogen peroxide produced by the starter cultures $[42,78]$. In addition, starter cultures grow faster, acidification occurs rapidly, and fermentation times are much shorter in their presence which resulted in reduced availability of nutrients [68]; thus, probiotic cultures do not have time to grow extensively.

The use of higher inocula of bifidobacteria and the addition of growth promoting factors as a nitrogen source should further enhance the growth and viability of the bifidobacteria [25, 26]. High inoculum levels must be used because a food product should contain between 1 and 100 million bifidobacteria per gram when placed on store shelves. Hence, it is recommended that during the manufacture of dairy products with bifidobacteria, the milk should be inoculated with the final number of bifidobacteria required for the product.

The addition of yeast extracts, casein hydrohysates or combination of amino acids, minerals and ribonucleotides or casein hydrolysates, amino acids, peptides and other micronutrients to supplement the growth of bifidobacteria in milk can be beneficial. However, the redox conditions might be inappropriate for growth of the bifidobacteria. Redox conditions indeed appear to be linked to the growth-promoting properties of various supplements [31]. In yoghurtlike product, the addition of ascorbic acid and cysteine decreased the redox potential, providing an environment more favourable to the growth of bifidobacteria $[15,16]$.

Oxygen may affect bifidobacteria due its toxicity to cells and production of $\mathrm{H}_{2} \mathrm{O}_{2}$, presumably due to intracellular production of $\mathrm{H}_{2} \mathrm{O}_{2}$ and by the $\mathrm{H}_{2} \mathrm{O}_{2}$ produced by other cultures in the environment [68]. A synergistic inhibition of bifidobacteria by acid and hydrogen peroxide has been demonstrated [38]. Bifidobacteria are considered as highly susceptible to oxygen although the oxygen tolerance of these organisms is species dependent $[17,69]$ because $B$. animalis 
subsp. lactis, isolated from fermented milk was found to display good oxygen tolerance [45]. With respect to susceptibility to oxygen, a particularly important feature for growth and stability of bifidobacteria in milk and fermented milk, it has been shown that a correlation exists between the synthesis of NAD-oxidase and NADH-peroxidase and oxygen susceptibility of the bifidobacteria [69]. High levels of these enzymes were found in the most aerotolerant Bifidobacterium spp. It is believed that intracellular levels of $\mathrm{H}_{2} \mathrm{O}_{2}$ block fructose-6-phosphofructoketolase, a key enzyme in the sugar metabolism of bifidobacteria and therefore scavenging $\mathrm{H}_{2} \mathrm{O}_{2}$ becomes important for cell survival [17]. Bifidobacterium spp. is devoid of catalase, a key enzyme for the breakdown of $\mathrm{H}_{2} \mathrm{O}_{2}$ and has to rely on enzymes such as NADH oxidase and NADH peroxidase to scavenge environmental oxygen. The activities of NADH oxidases in bifidobacteria give rise to $\mathrm{H}_{2} \mathrm{O}_{2}$, prompting NADH peroxidase to scavenge $\mathrm{H}_{2} \mathrm{O}_{2}$ and prevent cell death.

Some species of probiotics are more oxygen tolerant than the others [45]. Hence, creating an anaerobic environment during yoghurt-like product manufacture should promote the development of Bifidobacterium spp. Klaver et al. [35] found this to be the case, by influencing redox values with ascorbic acid. Yoghurt cultures that have proteolytic or oxygen-scavenging properties have been shown to be beneficial to bifidobacteria and could be considered in the selection of cultures compatible to probiotic strains [52]. It seems possible to affect $\mathrm{H}_{2} \mathrm{O}_{2}$ synthesis by bifidobacteria by taking advantage of the benefits of propionic cultures. Propionibacterium freudenreichii produced extracellularly growth stimulator(s) for bifidobacteria, which appeared to be different from propionic acid. A bifidogenic growth stimulator produced by $P$. freudenreichii was purified by Mori et al. [47]. The chemical structure of the bifidogenic growth stimulator was 2-amino-3-carboxy-1,4naphthoquinone (ACNQ). It has been shown that this molecule plays a role to modify the environment of bifidobacteria, thus creating favourable conditions for them to proliferate. The production of $\mathrm{H}_{2} \mathrm{O}_{2}$ that is detrimental for bifidobacteria under aerobic conditions is effectively suppressed in the presence of the bifidogenic growth stimulator. ACNQ acts as a mediator of the electron transfer from $\mathrm{NAD}(\mathrm{P}) \mathrm{H}$ to dioxygen $\left(\mathrm{O}_{2}\right)$ and hydrogen peroxide $\left(\mathrm{H}_{2} \mathrm{O}_{2}\right)$. The generation of $\mathrm{H}_{2} \mathrm{O}_{2}$ by $B$. longum under aerobic conditions is effectively suppressed in the presence of ACNQ. These ACNQmediated reactions would play roles as $\mathrm{NAD}(\mathrm{P})(+)$-regeneration processes [80].

The production of functional cheeses was recently proposed as a suitable and promising alternative as vehicle carrying probiotics as compared to fermented milks because the cheese could offer certain advantages (Tab. I). The cheeses having higher $\mathrm{pH}(\mathrm{pH}$ range 4.8-5.6) than fermented milks ( $\mathrm{pH} 3.7-4.3$ ) can provide a more stable medium to support the longterm survival of probiotics. Moreover, the cheese matrix and the high lipid content of cheeses can protect them during during processing and digestion $[18,72]$. In addition, an anaerobic environment will be developed due to the metabolism of lactic flora within a few weeks of ripening, favoring the survival of bifidobacteria [77]. Bifidobacteria have been used as probiotic culture to produce Cottage cheese, Crescenza, Cheddar, Fresco, fresh or white-brined cheeses, Canestrato Pugliese cheese made of ewe's milk [5, 12, 13, 18, 23, 26, 54, 79, 81] and Swiss-type cheese (Roy D., Mainville I., Bélanger G., unpublished). Roy et al. [58] studied the growth and acid production of bifidobacteria in milk under conditions typical of cheese-making, and evaluated the survival of the selected strains during storage in the presence of starters used for cheese-making. The bifidobacteria species differed in their ability to grow in different media, including milk, rennetted milk, and acidified milk in the presence of starter cultures and in their ability to produce acetic and lactic acids. B. longum strains demonstrated high survival rates in 
Table I. Use and stability of bifidobacteria in cheeses.

\begin{tabular}{|c|c|c|c|c|c|}
\hline Probiotics & $\begin{array}{l}\text { Type of } \\
\text { Cheese }\end{array}$ & Addition mode & $\begin{array}{l}\text { Storage } \\
\text { time }\end{array}$ & Stability during storage & Ref. \\
\hline \multirow[t]{7}{*}{ Bifidobacterium } & Cottage & B. infantis grown in the cream dressing & $14 \mathrm{~d}$ & $\begin{array}{l}\text { Bifidobacterium viability drops between } 0.5 \text { and } 3 \mathrm{log} \\
\text { during } 14 \mathrm{~d} \text { of storage at } 4{ }^{\circ} \mathrm{C} \text { as a function of strain }\end{array}$ & {$[4,5]$} \\
\hline & Crescenza & $\begin{array}{l}10^{6} \mathrm{cfu} \cdot \mathrm{mL}^{-1} \text { of milk from } B . \text { bifidum, } B . \text { infantis and } \\
\text { B. longum incorporated individually or as multispecies } \\
\text { mixtures and as free cells or as cells immobilized } \\
\text { in calcium alginate gel }\end{array}$ & $14 \mathrm{~d}$ & $\begin{array}{l}\text { B. bifidum and } B \text {. longum were at } \log 8.05 \text { and } \\
7.12 \mathrm{cfu} \cdot \mathrm{g}^{-1} \text {, respectively, which were similar to numbers } \\
\text { found at } 1 \mathrm{~d} \text { of ripening. Bifidobacterium infantis gradually } \\
\text { decreased to a final cell number of } \log 5.23 \mathrm{cfu} \cdot \mathrm{g}^{-1}\end{array}$ & {$[23]$} \\
\hline & \multirow[t]{3}{*}{ Cheddar } & 1. B. bifidum added to salted, milled curds & $168 \mathrm{~d}$ & $\begin{array}{l}\text { 1. B. bifidum increased from } 10^{6} \text { to } 10^{7} \mathrm{cfu} \cdot \mathrm{g}^{-1} \text { cheese } \\
\text { during } 24 \mathrm{wks} \text { storage }\end{array}$ & {$[18]$} \\
\hline & & $\begin{array}{l}\text { 2. } 10^{8} \mathrm{cfu} \cdot \mathrm{mL}^{-1} \text { of milk from a freeze-dried powder } \\
\text { culture of B. lactis or B. longum }\end{array}$ & $184 \mathrm{~d}$ & $\begin{array}{l}\text { 2. B. lactis survived at high numbers }\left(\times 10^{8} \mathrm{cfu} \cdot \mathrm{g}^{-1} \mathrm{cheese}\right) \text {, } \\
\text { while numbers of } B \text {. longum were reduced to } 10^{5} \mathrm{cfu} \cdot \mathrm{g}^{-1} \\
\text { cheese, following six months of ripening }\end{array}$ & {$[44]$} \\
\hline & & 3. Enriched cream fermented by $B$. infantis & $84 \mathrm{~d}$ & $\begin{array}{l}\text { 3. Loss of } 0.5 \log B \text {. infantis during first week, but stable } \\
\text { during the following } 11 \mathrm{wks}\end{array}$ & {$[13]$} \\
\hline & $\begin{array}{l}\text { Canestrato } \\
\text { Pugliese }\end{array}$ & $\begin{array}{l}10^{7} \mathrm{cfu} \text { of fresh cells per gram of B. bifidum, } \\
\text { B. longum, or both species }\end{array}$ & $90 \mathrm{~d}$ & $\begin{array}{l}\text { B. bifidum cells survived in cheeses at concentrations up to } \\
6 \log \mathrm{cfu} \cdot \mathrm{g}^{-1} \text { for at least } 90 \mathrm{~d} \text { of ripening. B. longum } \\
\text { showed a lower survival, reaching a value of } \\
5.0 \log \mathrm{cfu} \cdot \mathrm{g}^{-1} \text { at } 56 \mathrm{~d}\end{array}$ & {$[12]$} \\
\hline & $\begin{array}{l}\text { Fresh } \\
\text { cheese }\end{array}$ & $\begin{array}{l}10^{8} \mathrm{cfu} \cdot \mathrm{mL}^{-1} \text { of milk from a freeze-dried powder } \\
\text { culture of } B . \text { breve or B. longum }\end{array}$ & $57 \mathrm{~d}$ & $\begin{array}{l}\text { Bifidobacteria viable counts dropped between } 5 \text { and } 6 \log \\
\text { after } 36 \mathrm{~d} \text { of storage at } 4 \text { or } 12{ }^{\circ} \mathrm{C}\end{array}$ & {$[60]$} \\
\hline \multirow[t]{2}{*}{$\begin{array}{l}\text { Bifidobacterium } \\
\text { and L. acidophilus }\end{array}$} & $\begin{array}{l}\text { Semi-hard } \\
\text { goat cheese }\end{array}$ & $\begin{array}{l}\text { Starter concentrates of } B \text {. lactis and } L \text {. acidophilus } \\
\text { added at different inoculum levels }\end{array}$ & $70 \mathrm{~d}$ & $\begin{array}{l}\text { B. lactis and Lb. acidophilus lost up to } 1 \log \text { during } 70 \mathrm{~d} \\
\text { of storage }\end{array}$ & {$[24]$} \\
\hline & Gouda & L. acidophilus and Bifidobacterium sp. as starters & $70 \mathrm{~d}$ & $\begin{array}{l}\text { B. lactis decreased by one to two } \log \text { to } 0.75 \text { to } 10 \times \\
10^{7} \mathrm{cfu} \cdot \mathrm{g}^{-1} \text { and } \mathrm{L} \text {. acidophilus decreased by one } \log \text { cycle } \\
\text { to } 0.6 \text { to } 3 \times 10^{7} \mathrm{cfu} \cdot \mathrm{g}^{-1} \text { within } 70 \mathrm{~d} \text { of ripening }\end{array}$ & {$[26]$} \\
\hline $\begin{array}{l}\text { Bifidobacterium, } \\
\text { L. acidophilus } \\
\text { and L. casei }\end{array}$ & $\begin{array}{l}\text { Argentinian } \\
\text { Fresco } \\
\text { cheese }\end{array}$ & $\begin{array}{l}\text { Frozen cultures (inoculum of } 1 \% \mathrm{wt} / \mathrm{wt} \text { ) of bifidobac- } \\
\text { teria (B. longum, B. bifidum, and Bifidobacterium sp.), } \\
\text { L. acidophilus and L. casei }\end{array}$ & $60 \mathrm{~d}$ & $\begin{array}{l}\text { After } 60 \mathrm{~d} \text { of storage, the decreases in colony counts were } \\
\text { lower than } 1 \log \text { order for bifidobacteria and null for } \\
\text { L. casei. Lower viability of } L \text { b. acidophilus during storage }\end{array}$ & [79] \\
\hline
\end{tabular}


the presence of mesophilic starters would be acceptable for use in cheese-making. However, B. adolescentis strains were unable to grow in conditions typical of cheese-making. In cheese manufacturing, Dinakar and Mistry [18] were concerned that the addition of $B$. bifidum with the starter might be detrimental to the culture because of the aerobic conditions of cheesemaking, the cooking conditions and the presence of the mesophilic starter. They thus opted for addition of dried bifidobacteria to the milled curds. Stanton et al. [72] indeed found that the bifidobacteria did not grow during cheese-making, presumably because of the redox conditions (filling of the cheese vat with milk aerates the milk).

Although in general, the results obtained for incorporation of bifidobacteria in cheese are promising, the success of addition of probiotic bacteria depends on species used as well as interactions with lactic starters, conditions of fermentation, final $\mathrm{pH}$ of the product, presence of oxygen, and storage temperature. Several factors which can influence the capacity of probiotic to survive in cheese and to remain active must be considered. These factors include (1) physiological state of probiotic cultures (if the cells are in logarithmic or stationary phase of growth), (2) physical conditions of storage of the product (for example, temperature), (3) chemical composition of the product to which probiotics are added (for example, acidity, content of sugars available, nitrogen sources, mineral content, water activity and oxygen content), and (4) possible interactions between probiotic cultures and starters (for example, bacteriocin production, antagonism and synergism). Four types different of interactions between probiotic and lactic starters are possible (stimulation, delay and inhibition of the growth and any effect). The interactions between probiotic and the cheese matrix and starters can be much more intense when probiotic bacteria are also used in the same time that starters. Careful strain selection is mandatory to warrant the survival of bifidobacteria in the cheese matrix. In the eval- uation of the viability of bifidobacteria in several types of cheeses, B. bifidum and $B$. longum were among the strains shown to demonstrate good viability through the processing and storage of the cheese. However, B. longum subsp. infantis and B. adolescentis demonstrated poor survivability and would be less preferable for incorporation into dairy products.

In cream cheeses produced with four cultures of bifidobacteria (B. breve, B. longum subsp. infantis, B. longum and B. bifidum), the growth of bifidobacteria during cheesemaking was not affected by the presence of Lc. lactis subsp. lactis and Lc. lactis subsp. cremoris in association or not with Lc. lactis subsp. lactis biovar diacetylactis and Leuconostoc mesenteroides. Addition of native phosphocaseinate to increase milk protein content and hence buffering capacity did not result in an increase of growth of bifidobacteria in cream cheese [1]. Cream dressing added to Cottage cheese was fermented by adding $B$. longum subsp. infantis. The buffering capacity of the cream was increased by the use of ultrafiltered retentate of milk [4]. Higher level of lactic acid production was observed whereas the addition of a tryptic casein hydrolyzate did not increase the fermentation rate of cream [4].

The temperature of the production of fresh cheese was the principal factor which has affected the growth of the bifidobacteria. The presence of bifidobacteria during the fermentation of milk did not influence the growth of the mixed cultures of lactic starters. However, the presence of bifidobacteria modified the final characteristics of cream cheese. A slight modification of the process such as a temperature of manufacture of $35{ }^{\circ} \mathrm{C}$ instead of $30{ }^{\circ} \mathrm{C}$ is thus favourable to the growth of bifidobacteria without affecting that of lactic leuconostocs and other bacteria in cream cheeses [1]. The survival reduction survival by the temperature of cooking must also be taken into account at the time of the manufacture and during the period of maturation of cheese such as Cheddar cheeses [13]. 
Daigle et al. [13] did not observe any growth of $B$. longum subsp. infantis during different steps of manufacture of Cheddar cheese. Ten minutes after addition of cheese starters, bifidobacteria counts were the same in the cheddar cheese-making milk as in the inoculum. After cooking, there was no decrease of the viable counts of bifidobacteria. There was an increase in the number of cells in the curd as expected. Bifidobacteria counts in curds were of $7.3 \log \mathrm{cfu} \cdot \mathrm{g}^{-1}$ in curd and of $5.7 \mathrm{log} \mathrm{cfu} \cdot \mathrm{g}^{-1}$ in whey [13]. These results were in agreement with those of Gomes et al. [26] who observed no growth of Bifidobacterium sp. strain Bo that was used as starter for the manufacture of Gouda cheese [26].

Although the most common processing stage at which to add the bifidobacteria to the milk would be in conjunction with the other starter cultures, other alternative processing protocols have been successful in incorporating the bifidobacteria into cheese and cultured dairy products. Many of these alternative protocols have been used to develop Cheddar cheese with bifidobacteria. Dinakar and Mistry [18] added commercial or immobilized freeze-dried strains of B. bifidum to the matrix of Cheddar cheese, following cheddaring and salting. In the production of Cheddar cheese, $B$. longum subsp. infantis was initially cultured in the cream prior to adding to the skim milk and inoculating with the lactococci starter cultures [13]. The production of acetic and lactic acids in the cream prior to the initiation of cheese-making reduced the time required for curd formation. At the beginning of storage of Cheddar cheese, Daigle et al. [13] observed that viable count of bifidobacteria was $7.3 \mathrm{log} \mathrm{cfu} \cdot \mathrm{g}^{-1}$ which was similar to the number of bifidobacteria estimated in curd at the draining. These results indicate that viability $B$. longum subsp. infantis did not decrease during cheese-making process.

\subsection{Stability during storage}

Viability of bifidobacteria in dairy products over a long shelf-life at refrigeration temperatures remains a problem in most of the fermented products, which are acidic in nature. Several factors have been claimed to affect the viability of probiotic cultures in fermented milk products. Acidity, $\mathrm{pH}$ and hydrogen peroxide have been identified to have an effect during manufacture and storage. Other factors, such as temperature of storage, oxygen content, concentrations of lactic acid and acetic acid also have been presumed to affect the viability of bifidobacteria $[15,68]$.

In yoghurt-like product, $\mathrm{pH}$, oxygen and starter production conditions have significant effects. The main factors for loss of viability of bifidobacteria have been attributed to the decrease in the $\mathrm{pH}$ of the medium and accumulation of organic acids as a result of growth and fermentation [68]. Hence, the manufacture of these products containing bifidobacteria requires the selection of strain with low susceptibility to acid [35]. Previous studies showed that not all strains of bifidobacteria exhibited equivalent stability during storage of dairy products $[35$, 70] suggesting that performance of strains should be evaluated individually prior to commercial use in new dairy fermented products. Viability of bifidobacteria and lactic acid bacteria in milk and yoghurt-like product remained above $10^{6} \mathrm{cfu} / \mathrm{ml}$ or $\mathrm{g}$ until the expiration date of the respective products sold in USA [70]. High bifidobacteria counts $\left(>10^{6} \mathrm{cfu} \cdot \mathrm{g}^{-1}\right)$ were also observed in commercial yoghurt-like products manufactured and sold in Germany and France even in yoghurt-like products with a pH as low as 4.0, suggesting selection of more acid-tolerant strains by the industry in these countries. Indeed, most bifidobacteria strains isolated from Central European and French milk products were classified and identified as $B$. animalis subsp. lactis which showed identity to $B$. animalis ATCC 27536 [59].

The survival of B. bifidum, B. breve, $B$. longum subsp. infantis and B. longum was drastically affected during storage of yoghurtlike product, except for yoghurt-like product 
with $B$. animalis used because viable counts remain $>10^{6} \mathrm{cfu} \cdot \mathrm{g}^{-1}$ after $28 \mathrm{~d}$ of storage at $4{ }^{\circ} \mathrm{C}$ [37]. The level of bifidobacteria were $<10^{6} \mathrm{cfu} \cdot \mathrm{g}^{-1}$ after $7 \mathrm{~d}$ of storage in yoghurtlike products made with $B$. bifidum, $B$. breve, $B$. longum subsp. infantis and B. longum. These results are in agreement with previous studies because the viable cells of bifidobacteria in yoghurt-like product could not be maintained in sufficient amounts $\left(>10^{6} \mathrm{cfu} \cdot \mathrm{g}^{-1}\right)$ for more than $1 \mathrm{wk}$ during storage at $4{ }^{\circ} \mathrm{C}[37,61]$. Enhancement of bifidobacterial cold- and/or acid-tolerance could increase the number of viable bifidobacteria ingested via refrigerated dairy products [43]. It has been observed that the non-commercial species, $B$. longum, generally had less cold- and acid-tolerance than the commercially used $B$. animalis subsp. lactis. The two species also responded very differently to cold-tolerance and acid-tolerance tests after exposure to multiple-adaptation and standard treatments. These differences indicate that stress-responses can be speciesdependent and that probiotic bifidobacteria strains should be carefully chosen for use in various foods or dietary supplements. The yoghurt fermentation process itself could be considered an acid adaptation treatment (pH drops from 6.5 to 4.7 in about $5 \mathrm{~h}$ ) [43]. The yoghurt-like product environment was shown to effectively enhance subsequent acid-tolerance of both untreated and treated $B$. animalis subsp. lactis, suggesting that acid-tolerance of certain probiotic bifidobacteria would be enhanced by addition of cells at the start of fermentation [43].

The problem of sensitivity to acidity of bifidobacteria in yoghurt-like product is increased by the fact that acidity may increase during storage. In yoghurt-like product, acidification may continue during cold storage, a phenomenon called post-acidification, and the $\mathrm{pH}$ may drop to 3.6. Because most strains of bifidobacteria are sensitive to $\mathrm{pH}$ values below 4.6, in practical applications, the $\mathrm{pH}$ value of the final product must be maintained above 4.6, otherwise the bifidobacterial population will decline rapidly. Hence, the loss of viability of bifi- dobacteria may thus be reduced if the $\mathrm{pH}$ of the final product is high or the ratio of streptococci and lactobacilli is modified. This inhibitory effect of starters on probiotics is major and, in commercial products, low levels of bifidobacteria are correlated the addition of the starters used for technological purposes. This has led to the development of fermented milks where the probiotic cultures are the only starters added. A few strategies have been developed to try to reduce the strong inhibiting effect of the starter strains on the probiotic cultures: omission of a portion of the starter strains, and changes in the respective inoculation rates are the most common. It appears important to select lactobacilli that have weak post-acidification properties, or to reduce and even exclude $L$. delbrueckii subsp. bulgaricus from the starter. Examples of such cultures are the so called ABT cultures (ABT standing for L. acidophilus, Bifidobacterium and S. thermophilus) [60].

Many studies suggest that consumption of synbiotic products has higher beneficial effects on the human health than probiotic or prebiotic products $[22,55,56]$. Prebiotic has been defined as "a nondigestible food ingredient that beneficially affects the host by selectively stimulating the growth and/ or activity of one or a limited number of bacteria in the colon" [20]. In this context, a prebiotic is a dietary ingredient that reaches the large intestine in an intact form and has a specific metabolism therein, one directed toward beneficial rather than harmful bacteria. Synbiotics are mixtures of prebiotics and probiotics that would benefit the host by improving survival and implantation of the selected microbial supplements [83]. Indeed, the presence of probiotic and prebiotic in a single food improved survival of probiotic bacteria during the storage of the product and during the passage of the intestinal tract. Moreover, the synbiotic product may allow an efficient implantation of probiotic bacteria in colonic microbiota because prebiotic has a stimulating effect on the growth and/or activities 
of the exogenous and the endogenous bacteria [55].

Synbiotic dairy products are already marketed in Europe and Japan. In synbiotic fermented milks, the strains of Lactobacillus acidophilus, Lactobacillus casei and Bifidobacterium subsp. (B. animalis, B. bifidum, $B$. breve, $B$. longum subsp. infantis and $B$. longum) are widely used as probiotic whereas fructo-oligosaccharides, galactooligosaccharides, lactulose and inulin-derived products are widely used as prebiotic [34]. The use of a mixture of probiotic and prebiotic results in an increasing of cost production that can slow down the development of new synbiotic products. The use of probiotic bacteria, which are able to synthesize prebiotics might overcome this limitation. Many authors reported the capacity of bifidobacteria to synthesize galacto-oligosaccharides [30, 37, 62].

High survival rates of bifidobacteria can be obtained in none or low fermented products such as fluid milk, ice cream, low-acid yoghurt-like product and cheese. It is recognized that Cheddar has a pH of 5.2, fresh cheeses are at 4.6, and yoghurt-like product has a $\mathrm{pH}$ of 4.2. During ripening, the $\mathrm{pH}$ of cheeses such as Camembert rises sometimes over 6.0. Ice cream and milk have $\mathrm{pH}$ values close to 6.5. Therefore there are substantial variations in the $\mathrm{pH}$ of dairy products, even within those that are fermented.

The success of the incorporation of bifidobacteria into cheeses is dependent on the bifidobacteria strains, the activity of lactic acid bacteria used in the manufacture of the cheese, the composition of the cheese, and the conditions of processing and ripening. Although numerous studies report great losses in viability of probiotic strains during the storage of yoghurt-like product, the data on cheese shows that bifidobacteria incorporated can be stable during storage (Tab. I). Thus, the $\mathrm{pH}$ value seems to be a critical factor in the stability of probiotic strains during storage. There are significant differences between species and strains with respect to survival in an acid environment.
Viability of bifidobacteria in cottage cheese declined rapidly after 15 days of storage at $4{ }^{\circ} \mathrm{C}$ because the $\mathrm{pH}$ and titratable acidity of this product did not favor the bifidobacteria survival (Tab. I). In fact, strains of bifidobacteria do not have the same stability during maturation and storage of cheeses, suggesting that the survival of strains must be evaluated individually in the various types of cheese before their commercial use. In Cottage cheese, the survival of B. longum subsp. infantis was moderate [5]. In Cheddar cheese, B. longum subsp. infantis and $B$. bifidum remained viable during 12 and 24 wks, respectively [13, 18]. Daigle et al. [13] did not observe any significant difference for the viable count of bifidobacteria during storage at $4{ }^{\circ} \mathrm{C}$. Through a 12 -week storage period, counts of bifidobacteria did not change significantly and were maintained at levels higher than $10^{6} \mathrm{cfu} \cdot \mathrm{g}^{-1}$ of cheese. The $B$. lactis Bb-12 strain survived at high number $\left(>10^{8} \mathrm{cfu} \cdot \mathrm{g}^{-1}\right.$ of cheese) as compared to B. longum BB536 $\left(10^{5} \mathrm{cfu} \cdot \mathrm{g}^{-1}\right)$ after six months of ripening of Cheddar [44]. B. bifidum and B. longum exhibited better survival in Crescenza cheese than B. longum subsp. infantis during a period of $14 \mathrm{~d}$ of storage. At the first day after manufacture of white-brined cheese, while the counts of $B$. bifidum BB-02 in cheeses inoculated at levels of $2.5 \%$ and $5.0 \%$ were $7.0 \times$ $10^{8} \mathrm{cfu} \cdot \mathrm{g}^{-1}$ and $1.2 \times 10^{9} \mathrm{cfu} \cdot \mathrm{g}^{-1}$, respectively, these figures dropped to $4.0 \times$ $10^{6} \mathrm{cfu} \cdot \mathrm{g}^{-1}$ and $1.1 \times 10^{7} \mathrm{cfu} \cdot \mathrm{g}^{-1}$ after $90 \mathrm{~d}$ in the same order [81]. The traditional technology of manufacture of Canestrato Pugliese cheese made of ewe's milk was slightly modified to support the survival of the probiotic bacteria inoculated at a rate of $7.0 \mathrm{log}$ $\mathrm{cfu} \cdot \mathrm{g}^{-1}$. After $56 \mathrm{~d}$ of maturation, the survival of B. bifidum and B. longum was 6.0 and $5.0 \mathrm{log} \mathrm{cfu} \cdot \mathrm{g}^{-1}$, respectively [12]. The use of bifidobacteria and L. acidophilus as probiotic culture or starter for the manufacture of half-firm goat's milk cheese and Gouda showed that these probiotic bacteria had a satisfactory viability $\left(10^{6} \mathrm{cfu} \cdot \mathrm{g}^{-1}\right)$ during at least 9 wks $[24,26]$. Finally, the survival of the bifidobacteria, L. acidophilus 
and $L$. case $i$ was also satisfactory in the Fresco cheese. After $60 \mathrm{~d}$ of storage, the reductions in viable counts were lower than one $\log \mathrm{cfu} \cdot \mathrm{g}^{-1}$ for bifidobacteria [78].

Blanchette et al. [5] observed that in the Cottage cheese that the probiotic culture of B. longum subsp. infantis introduced at the time of the addition of the cream to the cheese curds could reach $7.0 \mathrm{log} \mathrm{cfu} \cdot \mathrm{g}^{-1}$ of cheese after $1 \mathrm{~d}$ of storage, but they observed a fast decline of their viability after $15 \mathrm{~d}$ of storage to $4{ }^{\circ} \mathrm{C}$. The $\mathrm{pH}$ and titratable acidity of this product did not favour the survival of this strain of bifidobacteria. However, these authors observed that this strain modified the content lactose significantly in the Cheese Cottage [5].

Roy et al. [60] used strains of $B$. breve and $B$. longum to produce a fresh cheese in combination with strains of Lactococcus lactis subsp. lactis and Lc. lactis subsp. cremoris. The final $\mathrm{pH}$ of cheese was higher than that of the cheese Cottage ( $\mathrm{pH}$ 4.6). The cheeses were stored at two temperatures $\left(4\right.$ and $\left.12{ }^{\circ} \mathrm{C}\right)$. The populations of bifidobacteria could be maintained longer at a rate higher than $6 \log \mathrm{cfu} \cdot \mathrm{g}^{-1}$. The survival of $B$. breve and $B$. longum was higher at $12{ }^{\circ} \mathrm{C}$ than at $4{ }^{\circ} \mathrm{C}$ because, the survival of lactococci was lower at $12{ }^{\circ} \mathrm{C}$. These authors also noted that the presence of bifidobacteria had an effect on the biochemical changes of fresh cheese. The lactose concentration decreased more strongly in cheeses containing bifidobacteria than in control cheese [60].

The survival of various strains of bifidobacteria in Swiss-type cheeses has been studied (Roy D., Mainville I., Bélanger G., unpublished). The process had to be modified in order to be able to add the bifidobacteria to cheeses. The modifications made to the original process were the reduction of the temperature of cooking of $53.5{ }^{\circ} \mathrm{C}$ with $41{ }^{\circ} \mathrm{C}$ and addition of a delactosing step in order to create a shock, similar to that of the temperature of cooking on starters. The use of a temperature of the warm room of $22^{\circ} \mathrm{C}$ has a drastic effect on survival of the bifi- dobacteria while a temperature of $16^{\circ} \mathrm{C}$ has little effect on survival of those, in particular for B. bifidum (Tab. II). The various lactic starter cocktails have few effects on the fate of bifidobacteria. However, it has been observed that the presence of $B$. bifidum during the period of storage led to a delay of growth of propionibacteria (Tab. III). Those developed more quickly at $22{ }^{\circ} \mathrm{C}$ although the final number is not different between the two temperatures for the warm room.

\subsection{Changes in sensory properties}

Changes in the chemical composition and the texture of the fermented products can occur in cheeses and fermented milks. In yoghurt-like product, it is possible to observe that the level of metabolites (mainly acetic acid) produced by the bacterial strain(s) can influence the organoleptic assessment [76]. Stanton et al. [72] noted that no difference between cheeses produced with or without $B$. infantis with regard to chemical and organoleptic properties of cheeses was obtained. In Cheddar cheese, bifidobacteria remained metabolically active during the storage period, but did not adversely affect the sensory characteristics and composition of the cheese without any adverse impact on organoleptic properties [13]. The residual lactose in cream cheese containing $B$. breve, $B$. bifidum and $B$. longum subsp. infantis was lower than that of cheese made without bifidobacteria and those containing $B$. longum. The cream cheese without bifidobacteria contained less acetaldehyde than those with bifidobacteria. The concentration of diacetyl was lower in the presence of bifidobacteria. The concentration of ethanol increased when bifidobacteria were employed with the mixed cultures of lactococci, aromatic lactococci and leuconostocs [1]. The higher amount of acetaldehyde might be due to the metabolism of bifidobacteria. Yuguchi et al. [82] mentioned that the strains $B$. longum, $B$. bifidum and $B$. breve produced acetaldehyde. 
Table II. Fate of Bifidobacterium bifidum during manufacture of Swiss-type cheeses (Roy D., Mainville I., Bélanger G., unpublished).

\begin{tabular}{lccccccc}
\hline Starter cultures & $\begin{array}{c}\text { Warm room } \\
\text { temperature }\end{array}$ & \multicolumn{5}{c}{$\begin{array}{c}\text { Viable counts } \\
\left(\text { log cfu-g }{ }^{-1}\right)\end{array}$} \\
\cline { 3 - 8 } & & & \multicolumn{5}{c}{ Ripening period (days) } \\
& & 1 & 22 & 36 & 43 & 50 & 71 \\
\hline TA & & 8.42 & 7.89 & 7.83 & 7.41 & 7.10 & 7.17 \\
TA+MA & $16{ }^{\circ} \mathrm{C}$ & 8.49 & 8.10 & 7.67 & 7.40 & 7.00 & 6.75 \\
TA+LH & & 8.48 & 8.15 & 7.60 & 7.61 & 7.36 & 7.43 \\
TA+MA+LH & & 8.66 & 8.15 & 7.94 & 7.52 & 7.12 & 6.60 \\
& & & & & & & \\
TA & & 8.41 & 7.90 & 6.56 & 5.37 & 4.64 & 3.26 \\
TA+MA & $22{ }^{\circ} \mathrm{C}$ & 8.44 & 7.98 & 5.60 & 3.78 & 3.43 & 2.92 \\
TA+LH & & 8.30 & 8.00 & 6.49 & 5.69 & 2.84 & 2.00 \\
TA+MA+LH & & 8.24 & 8.24 & 5.88 & 4.98 & 4.39 & 3.63 \\
\hline
\end{tabular}

Starters used:

TA: Streptococcus salivarius subsp. thermophilus (TA 060);

MA: Lactococcus lactis subsp. lactis and L. lactis subsp. lactis (MA 011);

LH: Lactobacillus helveticus and L. delbrueckii subsp. lactis (LH 100), Propionibacterium freudenreichii subsp. shermanii, B. bifidum R071.

Small scale experimental Swiss cheeses were made from pasteurized milk by a standard procedure described previously $[9,32]$. Eight cheeses were produced and three repetitions were carried out. Samples were taken just after brining (day 1), at the end (day 22) of the time in the cold room $\left(12{ }^{\circ} \mathrm{C}\right.$ ), twice (days 36-43) during the time in the warm room $\left(16{ }^{\circ} \mathrm{C}\right.$ or $22^{\circ} \mathrm{C}$ ), at the end (day 50) of the time in the warm room, and after 21 days at cold storage (day 71).

The production of acetaldehyde by bifidobacteria and the transformation of this product into ethanol by the leuconostocs and their ability to transform lactose into pyruvate or ethanol can also explain the greater ethanol concentration in cream cheeses containing bifidobacteria as compared with those without bifidobacteria.

Finally, the economical consequences such as price, market positioning, advertising, and understanding of market conditions and consumer attitudes for the production of the functional cheeses are not well-known but it is important to take in consideration that the interest in and acceptance of functional foods is gaining momentum. A strong health claim or inference, although being an important purchase motivator, does not guarantee a product's success. The customer must be encouraged to repeat the purchase, which may not happen if the benefits of the product are not identified. If the product can offer something measurable to the consumer in the long term, there is a greater chance of repeat buying [73]. Sensorial attributes in this respect are as important as health attributes.

\section{CONCLUSION}

The functional cheese may be more effective than yoghurt-like product to deliver probiotic bacteria to the intestinal tract. It is possible to include bifidobacteria in the traditional production of Cheddar cheese and fresh cheeses. It is also possible to produce Swiss-type cheese after slight modifications. Bifidobacteria do not deteriorate the product, enhance the development of flavours in fresh cheeses and give to the products a functional character. 
Table III. Fate of Propionibacterium freudenreichii subsp. shermanii during manufacture of Swiss-type cheeses (Roy D., Mainville I., Bélanger G., unpublished).

\begin{tabular}{|c|c|c|c|c|c|c|c|}
\hline \multirow[t]{3}{*}{ Starter cultures } & \multirow[t]{3}{*}{$\begin{array}{l}\text { Warm room } \\
\text { temperature }\end{array}$} & \multicolumn{6}{|c|}{$\begin{array}{l}\text { Viable counts } \\
\left(\log \mathrm{cfu} \cdot \mathrm{g}^{-1}\right)\end{array}$} \\
\hline & & \multicolumn{6}{|c|}{ Ripening period (days) } \\
\hline & & 1 & 22 & 36 & 43 & 50 & 71 \\
\hline \multicolumn{8}{|l|}{ Control } \\
\hline TA & \multirow{8}{*}{$16^{\circ} \mathrm{C}$} & 6.23 & 8.81 & 8.78 & 8.90 & 8.90 & 8.89 \\
\hline $\mathrm{TA}+\mathrm{MA}$ & & 6.28 & 7.32 & 8.68 & 8.97 & 9.08 & 9.00 \\
\hline $\mathrm{TA}+\mathrm{LH}$ & & 6.26 & 7.54 & 8.79 & 9.00 & 8.90 & 8.97 \\
\hline $\begin{array}{l}\mathrm{TA}+\mathrm{MA}+\mathrm{LH} \\
\text { B. bifidum }\end{array}$ & & 6.34 & 7.50 & 8.68 & 8.61 & 9.00 & 9.00 \\
\hline TA & & 6.29 & 7.94 & 8.40 & 8.70 & 8.72 & 8.90 \\
\hline $\mathrm{TA}+\mathrm{MA}$ & & 6.27 & 7.30 & 8.73 & 8.67 & 8.90 & 8.95 \\
\hline $\mathrm{TA}+\mathrm{LH}$ & & 6.33 & 6.78 & 8.30 & 8.58 & 8.68 & 8.81 \\
\hline $\mathrm{TA}+\mathrm{MA}+\mathrm{LH}$ & & 6.35 & 7.26 & 8.47 & 8.56 & 8.64 & 8.76 \\
\hline \multicolumn{8}{|l|}{ Control } \\
\hline TA & \multirow{8}{*}{$22{ }^{\circ} \mathrm{C}$} & 6.26 & 8.52 & 9.22 & 9.23 & 9.14 & 9.05 \\
\hline $\mathrm{TA}+\mathrm{MA}$ & & 6.40 & 7.87 & 9.26 & 9.33 & 9.12 & 8.98 \\
\hline $\mathrm{TA}+\mathrm{LH}$ & & 6.18 & 7.74 & 9.19 & 9.04 & 8.96 & 8.93 \\
\hline $\begin{array}{l}\mathrm{TA}+\mathrm{MA}+\mathrm{LH} \\
\text { B. bifidum }\end{array}$ & & 6.31 & 7.94 & 9.21 & 9.06 & 8.92 & 8.68 \\
\hline TA & & 6.36 & 7.98 & 9.22 & 9.22 & 9.06 & 8.96 \\
\hline $\mathrm{TA}+\mathrm{MA}$ & & 6.33 & 8.08 & 9.27 & 9.23 & 8.96 & 8.93 \\
\hline $\mathrm{TA}+\mathrm{LH}$ & & 6.27 & 7.32 & 9.02 & 8.93 & 8.88 & 8.88 \\
\hline TA+MA+LH & & 6.39 & 7.16 & 9.01 & 8.89 & 8.84 & 8.63 \\
\hline
\end{tabular}

Starters used:

TA: Streptococcus salivarius subsp. thermophilus (TA 060);

MA: Lactococcus lactis subsp. lactis and L. lactis subsp. lactis (MA 011);

LH: Lactobacillus helveticus and L. delbrueckii subsp. lactis (LH 100), Propionibacterium freudenreichii subsp. shermanii, B. bifidum R071.

Small scale experimental Swiss cheeses were made from 10 pasteurized milk by a standard procedure described previously $[9,32]$. Eight cheeses were produced and three repetitions were carried out. Samples were taken just after brining (day 1), at the end (day 22) of the time in the cold room $\left(12{ }^{\circ} \mathrm{C}\right)$, twice (days 36-43) during the time in the warm room $\left(16^{\circ} \mathrm{C}\right.$ or $22{ }^{\circ} \mathrm{C}$ ), at the end (day 50) of the time in the warm room, and after 21 days at cold storage (day 71).

Acknowledgements: I thank Sylvie Lortal and the organisers of the first Symposium on Propionibacteria and Bifidobacteria who invited me to present my work. I would like also thank Francine Mondou for her scientific assistance and Isabelle Mainville and Gaétan Bélanger for their technical assistance.

\section{REFERENCES}

[1] Baron M., Roy D., Vuillemard J.C., Biochemical characteristics of fermented milk produced by mixed-cultures of lactic starters and bifidobacteria, Lait 80 (2000) 465-478.

[2] Berrada N., Lemeland J.-F., Laroche G., Thouvenot P., Piaia M., Bifidobacterium 
from fermented milks: Survival during gastric transit, J. Dairy Sci. 74 (1991) 409-413.

[3] Bezkorovainy A., Probiotics: determinants of survival and growth in the gut, Am. J. Clin. Nutr. 73 (2001) 399S-405S.

[4] Blanchette L., Roy D., Gauthier S.F., Production of cultured cottage cheese dressing by bifidobacteria, J. Dairy Sci. 78 (1995) 1421-1429.

[5] Blanchette L., Roy D., Bélanger G., Gauthier S.F., Production of Cottage cheese using dressing fermented by bifidobacteria, J. Dairy Sci. 79 (1996) 8-15.

[6] Bouhnik Y., Pochart P., Marteau P., Arlet G., Goderel I., Rambaud J.C., Fecal recovery in humans of viable Bifidobacterium sp. ingested in fermented milk, Gastroenterology 102 (1992) 875-878.

[7] Bouhnik Y., Flourie B., Riottot M., Bisetti N., Gailing M.F., Guibert A., Bornet F., Rambaud J.C., Effects of fructo-oligosaccharides ingestion on fecal bifidobacteria and selected metabolic indexes of colon carcinogenesis in healthy humans, Nutr. Cancer 26 (1996) 21-29.

[8] Boylston T.D., Vinderola C.G., Ghoddusi H.B., Reinheimer J.A., Incorporation of bifidobacteria into cheeses: challenges and rewards, Int. Dairy J. 14 (2004) 375-387.

[9] Buisson V., Kerjean J.R., Courroye M., Miniaturization of cheese technology, Tech. Lait. Market. 1024 (1987) 17-23.

[10] Charteris W.P., Kelly P.M., Morell L., Collins J.K., Development and application of an in vitro methodology to determine the transit tolerance of potentially probiotic Lactobacillus and Bifidobacterium species in the upper human gastrointestinal tract, J. Appl. Microbiol. 84 (1998) 759-768.

[11] Charteris W.P., Kelly P.M., Morelli L., Collins J.K., Edible table (bio)spread containing potentially probiotic Lactobacillus and Bifidobacterium species, Int. J. Dairy Technol. 55 (2002) 44-56.

[12] Corbo M.R., Albenzio M., De Angelis M., Sevi A., Gobbetti M., Microbiological and biochemical properties of canestrato pugliese hard cheese supplemented with bifidobacteria, J. Dairy Sci. 84 (2001) 551-561.

[13] Daigle A., Roy D., Bélanger G., Vuillemard J.C., Production of probiotic cheese (cheddar-like cheese) using enriched cream fermented by Bifidobacterium infantis, J. Dairy Sci. 82 (1999) 1081-1091.

[14] Dave R.I., Shah N.P., Evaluation of media for selective enumeration of Streptococcus thermophilus, Lactobacillus delbrueckii ssp. bulgaricus, Lactobacillus acidophilus, and bifidobacteria, J. Dairy Sci. 79 (1996) 1529-1536.

[15] Dave R.I., Shah N.P., Effect of cysteine on the viability of yoghurt and probiotic bacteria in yoghurts made with commercial starter cultures, Int. Dairy J. (1997) 537-545.
[16] Dave R.I., Shah N.P., Ingredient supplementation effects on viability of probiotic bacteria in yogurt, J. Dairy Sci. 81 (1998) 2804-2816.

[17] de Vries W., Stouthamer A.H., Sensitivity of bifidobacteria to oxygen, J. Gen. Microbiol. 55 (1969) 13.

[18] Dinakar P., Mistry V.V., Growth and viability of Bifidobacterium bifidum in cheddar cheese, J. Dairy Sci. 77 (1994) 2854-2864.

[19] Gardiner G., Stanton C., Lynch P.B., Collins J.K., Fitzgerald G., Ross R.P., Evaluation of Cheddar cheese as a food carrier for delivery of a probiotic strain to the gastrointestinal tract, J. Dairy Sci. 82 (1999) 1379-1387.

[20] Gibson G.R., Fuller R., Aspects of in vitro and in vivo research approaches directed toward identifying probiotics and prebiotics for human use, J. Nutr. 130 (2000) 391S-395S.

[21] Gill H.S., Rutherfurd K.J., Viability and dose-response studies on the effects of the immunoenhancing lactic acid bacterium Lactobacillus rhamnosus in mice, Br. J. Nutr. 86 (2001) 28528-28529.

[22] Gmeiner M., Kneifel W., Kulbe K.D., Wouters R., De Boever P., Nollet L., Verstraete W., Influence of a synbiotic mixture consisting of Lactobacillus acidophilus 74-2 and a fructooligosaccharide preparation on the microbial ecology sustained in a simulation of the human intestinal microbial ecosystem (SHIME reactor), Appl. Microbiol. Biotechnol. 53 (2000) 219-223.

[23] Gobbetti M., Corsetti A., Smacchi E., Zocchetti A., De Angelis M., Production of Crescenza cheese by incorporation of bifidobacteria, $\mathrm{J}$. Dairy Sci. 81 (1998) 37-47.

[24] Gomes A.M.P., Malcata F.X., Development of probiotic cheese manufactured from goat milk: Response surface analysis via technological manipulation, J. Dairy Sci. 81 (1998) 1492-1507.

[25] Gomes A.M.P., Malcata F.X., Bifidobacterium spp., Lactobacillus acidophilus: Biological, biochemical, technological, and therapeutical properties relevant for use as probiotics, Trends Food Sci. Technol. 10 (1999) 139-157.

[26] Gomes A.M.P., Malcata F.X., Klaver F.A.M., Grande H.J., Incorporation of Bifidobacterium spp. strain Bo and Lactobacillus acidophilus strain $\mathrm{Ki}$ in a cheese product, Neth. Milk Dairy J. (1995) 71-95.

[27] He F., Ouwehan A.C., Hashimoto H., Isolauri E., Benno Y., Salminen S., Adhesion of Bifidobacterium spp. to human intestinal mucus, Microbiol. Immunol. 45 (2001) 259-262.

[28] Holzapfel W.H., Haberer P., Snel J., Schillinger U., Huis in't Veld J.H., Overview of gut flora and probiotics, Int. J. Food Microbiol. 41 (1998) 85-101. 
[29] Holzapfel W.H., Haberer P., Geisen R., Bjorkroth J., Schillinger U., Taxonomy and important features of probiotic microorganisms in food and nutrition, Am. J. Clin. Nutr. 73 (2001) 365S-373S.

[30] Hung M.N., Lee B.H., Purification and characterization of a recombinant beta-galactosidase with transgalactosylation activity from Bifidobacterium infantis HL96, Appl. Microbiol. Biotechnol. 58 (2002) 439-445.

[31] Ibrahim S.A., Bezkorovainy A., Growth-promoting factors for Bifidobacterium longum, J. Food. Sci. 59 (1994) 189-191.

[32] Kerjean J.R., Richoux R., Technological properties of pure propionibacteria strainstest in small-scale swiss-type cheese, Lait (1995) 45-59.

[33] Kirjavainen P.V., Ouwehand A.C., Isolauri E., Salminen S.J., The ability of probiotic bacteria to bind to human intestinal mucus, FEMS Microbiol. Lett. 167 (1998) 185-189.

[34] Klaenhammer T.R., Kullen M.J., Selection and design of probiotics, Int. J. Food Microbiol. 50 (1999) 45-57.

[35] Klaver F.A.M., Kingma F., Weerkamp A.H., Growth and survival of bifidobacteria in milk, Neth. Milk Dairy J. 47 (1993) 151-164.

[36] Klein G., Pack A., Bonaparte C., Reute G., Taxonomy and physiology of probiotic lactic acid bacteria, Int. J. Food Microbiol. 41 (1998) 103-125.

[37] Lamoureux L., Roy D., Gauthier S.F., Production of oligosaccharides in yogurt containing bifidobacteria and yogurt cultures, J. Dairy Sci. 85 (2002) 1058-1069.

[38] Lankaputhra W.E.V., Shah N.P., Britz M.L., Survival of bifidobacteria during refrigerated storage in the presence of acid and hydrogen peroxide, Milchwissenschaft 51 (1996) 65-70.

[39] Lee Y.-K., Salminen S., The coming of age of probiotics, Trends Food Sci. Technol. 6 (1995) 241-245.

[41] Marteau P., Minekus M., Havenaar R., Huis in't Veld J.H., Survival of lactic acid bacteria in a dynamic model of the stomach and small Intestine: Validation and the effects of bile, J. Dairy Sci. 80 (1997) 1031-1037.

[40] Marteau P., Shanahan F., Basic aspects and pharmacology of probiotics: an overview of pharmacokinetics, mechanisms of action and side-effects, Best Pract. Res. Clin. Gastroenterol. 17 (2003) 725-740.

[42] Mattila-Sandholm T., Myllärinen P., Crittenden R., Mogensen G., Fondén R., Saarela M., Technological challenges for future probiotic foods, Int. Dairy J. 12 (2002) 173-182.

[43] Maus J.E., Ingham S.C., Employment of stressful conditions during culture production to enhance subsequent cold- and acid-tolerance of bifidobacteria, J. Appl. Microbiol. 95 (2003) 146-154.
[44] McBrearty S., Ross R.P., Fitzgerald G.F., Collins J.K., Wallace J.M., Stanton C., Influence of two commercially available bifidobacteria cultures on Cheddar cheese quality, Int. Dairy J. 11 (2001) 599-610.

[45] Meile L., Ludwig W., Rueger U., Gut C., Kaufman P., Dasen G., Wenger S., Teuber M., Bifidobacterium lactis sp. nov., a moderaly oxygen tolerant species isolated from fermented milk system, Syst. Appl. Microbiol. 20 (1997) 57-64.

[46] Mitsuoka T., Significance of dietary modulation of intestinal microflora and intestinal environment, Biosci. Microflora 19 ( 2000) 15-25.

[47] Mori H., Sato Y., Taketomo N., Kamiyama T., Yoshiyama Y., Meguro S., Sato H., Kaneko T., Isolation and structural identification of bifidogenic growth stimulator produced by Propionibacterium freudenreichii, J. Dairy Sci. 80 (1997) 1959-1964.

[48] O’Sullivan D.J., Kullen M.J., Tracking of probiotic bifidobacteria in the intestine, Int Dairy J. (1998) 513-525.

[49] Ouwehand A.C., Isolauri E., Kirjavainen P.V., Salminen S.J., Adhesion of four Bifidobacterium strains to human intestinal mucus from subjects in different age groups, FEMS Microbiol. Lett. 172 (1999) 61-64.

[50] Pochart P., Dewit O., Desjeux J.F., Bourlioux P., Viable starter culture, beta-galactosidase activity, and lactose in duodenum after yogurt ingestion in lactase-deficient humans, Am J. Clin. Nutr. 49 (1989) 828-831.

[51] Pochart P., Marteau P., Bouhnik Y., Goderel I., Bourlioux P., Rambaud J.C., Survival of bifidobacteria ingested via fermented milk during their passage through the human small intestine: an in vivo study using intestinal perfusion, Am J. Clin. Nutr. 55 (1992) 78-80.

[52] Reddy B.S., Prevention of colon cancer by pre- and probiotics: evidence from laboratory studies, Br. J. Nutr. 80 (1998) S219-S223.

[53] Reuter G., Klein G., Goldberg M., Identification of probiotic cultures in food samples, Food Res. Int. 35 (2002) 117-124.

[54] Riordan K.O., Fitzgerald G.F., Evaluation of bifidobacteria for the production of antimicrobial compounds and assessment of performance in cottage cheese at refrigeration temperature, J. Appl. Microbiol. 85 (1998) 103-114.

[55] Roberfroid M.B., Prebiotics and synbiotics: concepts and nutritional properties, Br. J. Nutr. 80 (1998) S197-S202.

[56] Rowland I.R., Tanaka R., The effects of transgalactosylated oligosaccharides on gut flora metabolism in rats associated with a human faecal microflora, J. Appl. Bacteriol. 74 (1993) 667-674. 
[57] Roy D., Media for the isolation and enumeration of bifidobacteria in dairy products, Int. J. Food Microbiol. 69 (2001) 167-182.

[58] Roy D., Desjardins M.L., Mondou F., Selection of bifidobacteria for use under cheesemaking condition, Milchwissenschaft 50 (1995) 139-142.

[59] Roy D., Ward P., Champagne G., Differentiation of bifidobacteria by use of pulsed-field gel electrophoresis and polymerase chain reaction, Int. J. Food Microbiol. 29 (1996) 11-29.

[60] Roy D., Mainville I., Mondou F., Selective enumeration and survival of bifidobacteria in fresh cheese, Int. Dairy J. 7 (1997) 785-793.

[61] Roy D., Mainville I., Mondou F., Bifidobacteria and their role in yogurt-related product, Microecol. Ther. 26 (1997) 167-180.

[62] Roy D., Daoudi L., Azaola A., Optimization of galacto-oligosaccharide production by Bifidobacterium infantis RW-8120 using response surface methodology, J. Ind. Microbiol. Biotechnol. 29 (2002) 281-285.

[63] Saarela M., Mogensen G., Fondén R., Matto J., Mattila-Sandholm T., Probiotic bacteria: safety, functional and technological properties, J. Biotechnol. 84 (2000) 197-215.

[64] Saarela M., Rantala M., Hallamaa K., Nohynek L., Virkajarvi I., Matto J., Stationaryphase acid and heat treatments for improvement of the viability of probiotic lactobacilli and bifidobacteria, J. Appl. Microbiol. 96 (2004) 1205-1214.

[65] Samona A., Robinson R.K., Effect of yogurt cultures on the survival of bifidobacteria in fermented milks, J. Soc. Dairy Technol. 47 (1994) 58-60.

[66] Sanders M.E., Walker D.C., Walker K.M., Aoyama K., Klaenhammer T.R., Performance of commercial cultures in fluid milk applications, J. Dairy Sci. 79 (1996) 943-955.

[67] Saxelin M., Grenov B., Svensson U., Fondén R., Reniero R.M., Mattila-Sandholm T., The technology of probiotics, Trends Food Sci. Technol. 10 (1999) 387-392.

[68] Shah N.P., Probiotic bacteria: selective enumeration and survival in dairy foods, J. Dairy Sci. 83 (2000) 894-907.

[69] Shimamura S., Abe F., Ishibashi N., Miyakawa H., Yaeshima T., Araya T., Tomita M., Relationship between oxygen sensitivity and oxygen metabolism of Bifidobacterium species, J. Dairy Sci. 75 (1992) 3296-3306.

[70] Shin H.S., Lee J.H., Pestka J.J., Ustunol Z., Viability of bifidobacteria in commercial dairy products during refrigerated storage, $\mathrm{J}$. Food Prot. 63 (2000) 327-331.

[71] Silva A.M., Barbosa F.H., Duarte R., Vieira L.Q., Arantes R.M., Nicoli J.R., Effect of Bifidobacterium longum ingestion on exper- imental salmonellosis in mice, J. Appl. Microbiol. 97 (2004) 29-37.

[72] Stanton C., Gardiner G., Lynch P.B., Collins J.K., Fitzgerald G., Ross R.P., Probiotic cheese, Int. Dairy J. 8 (1998) 491-496.

[73] Stanton C., Gardiner G., Meehan H., Collins K., Fitzgerald G., Lynch P.B., Ross R.P., Market potential for probiotics, Am. J. Clin. Nutr. 73 (2001) 476S-483S.

[74] Sun W., Griffiths M.W., Survival of bifidobacteria in yogurt and simulated gastric juice following immobilization in gellan-xanthan beads, Int. J. Food Microbiol. 61 (2000) 17-25.

[75] Takahashi N., Xiao J., Miyaji K., Yaeshiima T., Hiramatsu A., Iwatsuki K., Kokubo S., Hosono A., Selection of acid tolerant bifidobacteria and evidence for a low-pH-inducible acid tolerance response in Bifidobacterium longum, J. Dairy Res. (2004) 340-345.

[76] Tamime A.Y., Fermented milks: a historical food with modern applications - a review, Eur. J. Clin. Nutr. 56 (2002) S2-S15.

[77] Van den Tempel T., Gundersen J.K., Nielsen M.S., The microdistribution of oxygen in Danablu cheese measured by a microsensor during ripening, Int. Dairy J. 75 (2002) 157-161.

[78] Vinderola C.G., Prosello W., Ghiberto T.D., Reinheimer J.A., Viability of probiotic (Bifidobacterium, Lactobacillus acidophilus and Lactobacillus casei) and nonprobiotic microflora in Argentinian Fresco cheese, J. Dairy Sci. 83 (2000) 1905-1911.

[79] Vinderola C.G., Mocchiutti P., Reinheimer J.A., Interactions among lactic acid starter and probiotic bacteria used for fermented dairy products, J. Dairy Sci. 85 (2002) 721-729.

[80] Yamazaki S., Kano K., Ikeda T., Isawa K., Kaneko T., Role of 2-amino-3-carboxy-1,4naphthoquinone, a strong growth stimulator for bifidobacteria, as an electron transfer mediator for $\operatorname{NAD}(\mathrm{P})(+)$ regeneration in Bifidobacterium longum, Biochim. Biophys. Acta. 1428 (1999) 241-250.

[81] Yilmaztekin M., Ozer B.H., Atasoy F., Survival of Lactobacillus acidophilus LA-5 and Bifidobacterium bifidum BB-02 in whitebrined cheese, Int. J. Food Sci. Nutr. 55 (2004) 53-60.

[82] Yuguchi H., Hiramatsu A., Doi K., Idach O.S., Studies on the flavor of yoghurt fermented with Bifidobacteria: Significance of volatile components and organic acids in the sensory acceptance of yoghurt, Jpn. J. Zootech. Sci. 60 (1989) 734-741.

[83] Ziemer C.J., Gibson G.R., An overview of probiotics, prebiotics and synbiotics in the functional food concept: Perspectives and future strategies, Int. Dairy J. 8 (1998) 473-479. 